\title{
The 1988-1989 transformation in Poland. The authorities, the opposition, the Church
}

\begin{abstract}
The events that took place in Poland in 1988-1989 established a transformation model of which various elements tended to be replicated in other countries of the Soviet Bloc. Nevertheless, certain elements of the Polish transformation model were specific and unique, having sprouted from a specific historical context. The author of the paper proposes that the triad formed by "the authorities, the opposition and the Church" be considered a uniquely Polish aspect of the political and social transformation that took place after August 1980. The goal of this paper is to present this transformation with respect to each of the above three actors. An analysis of their concepts and actions leads to the conclusion that Poland should be considered an exceptional model of transformation in Central and Eastern Europe. The Polish transformation model featured a key and unique element, the Catholic Church - an institution that played a considerable role in making the 1988-1989 transformation nonconfrontational.
\end{abstract}

Key words: Systemic change 1989, Model of transformation 1989, Poland 1989, Catholic Church 1989

$\mathrm{s}$ tefan Kisielewski, aka "Kisiel," a prominent Polish musician, columnist and exceptionally harsh critic of the communist state, used to say of the recurrent crises plaguing politics, economy and society during the communist era: "this is not a crisis, this is an outcome." In this way, he captured a fundamental shortcoming of "real socialism;" as he perceived it, the advancing instability of the system heading towards collapse was a result of its intrinsic properties. The same viewpoint was also adopted by some people who had previously believed that the fundamental standards and principles of the system were correct, and it could be remedied by eliminating its various "errors and deviations." One example of this is the group known as the revisionists, who in the early 1960s tried to suggest that the political system of the Polish People's Republic should be thoroughly reformed while maintaining the fundamental principles rooted in the ideology of Marxism and Leninism. Towards the end of the 1960s, and especially after the events of March 1968, the outstanding representatives of these circles, Leszek Kołakowski, Jacek Kuron and Karol Modzelewski, realized that a profound change of the system was necessary, rather than simple reform (Gawin, 2015, pp. 280-310). Kisiel's "outcome" materialized in the late $1980 \mathrm{~s}$, a decade during which the political, social and economic dysfunctions of the system became permanent. The crisis peaked in 1988 and 1989, bringing about a political and social transformation with revolutionary consequences (Sztompka, 2007, pp. 283-285). This transformation was part of a broader process taking place throughout the Central and Eastern European states that had depended on the USSR until then. This process was primarily triggered by trans-regional, or even global, changes, such as the internal crisis in the USSR, the doomed attempts to save the Soviet empire by 
Gorbachev's perestroika, and the end of the Cold War, which concluded the era of the bipolar international order. A significant element of the changes in the USSR involved the abandonment of the Brezhnev Doctrine, also called the "Doctrine of Limited Sovereignty," which justified the armed intervention of the Warsaw Pact in the "rebellious" states of the Soviet Bloc (Paczkowski, 2002, p. 197). Such an intervention being feasible had long been one of the most important factors legitimizing the rule of communist parties in these countries and an argument to pacify opposition sentiments. The example of the "Solidarity Carnival" in 1980-1981 demonstrated that potential intervention was another factor that restrained the radicalization of the opposition, both in terms of their views and actions, and led to self-restraint which counteracted the logic of revolution. In the countries in the Soviet sphere of influence, Poland in particular, this translated to a change with fundamental consequences: for the first time, it became realistic to pursue increased autonomy from the Kremlin and to legalize the actions of non-communist groups and parties. In practice, this meant that the implementation of the "Finlandization model" might have been possible. For the first time, the ruling elite faced the possibility of losing power, which would be approved by Moscow to boot. The Communist Party leaders must have been horrified by the Kremlin attempts to seek contact with prominent Polish opposition leaders, which became visible in 1988 (Zmierzch..., 2013, p. 303). The deteriorating economy of the country and the resulting rise of social dissatisfaction, which might have translated into mass demonstrations by a disgruntled society, gained exceptional importance. The combination of external and internal circumstances resulted in the ruling elite having to accept the need for profound systemic changes.

The most intensive period of changes started at the end of August 1988, when the head of the Ministry of the Interior, General Czesław Kiszczak, officially met the leader of the Solidarity National Executive Committee Lech Wałęsa for the first time, and ended one year later when the government of PM Tadeusz Mazowiecki was formed. The events that took place in Poland over this period established a model of transformation with numerous elements, for instance "the Round Table," replicated in other countries of the Soviet Bloc (Wojnicki, 2006, pp. 119-143). Nevertheless, certain elements of the Polish transformation model were specific and unique, having emerged from a specific historical context. One such element involves the three elements which are the topic of this paper, namely "the authorities, the opposition and the Church" - the main actors on the stage of political and social transformation that had begun in Poland by at least August 1980. My task is not to present a detailed account of the actions of each of these actors but rather to draw a general map to indicate the various determinants of these actions, and thereby help readers to navigate through complicated and dynamic context of the time of the great transformation.

\section{The authorities}

In the second half of the 1980s, the Polish United Workers' Party, whose structures had ruled the country in the political system of Poland at that time, was suffering from what Antoni Dudek named "the erosion of the Party spine" (Dudek, 2004, p. 40). The 1980-1981 crisis, followed by the shock of martial law, brought about a mass exodus of 
Party members. Approximately one million members cancelled their membership, primarily younger people who were more active and enterprising. There were at least two reasons making it impossible to easily compensate for this loss. One was the fact that a large proportion of young people had been shaped by the unique atmosphere of "the Revolution of Solidarity" and rejected the possibility of getting involved in the ruling structures for ideological reasons. Another, more practically-oriented group did not see a Party career as very attractive; they took advantage of the possibility of going abroad, or the new opportunities provided by the fledgling private sector. The Party elite was aging, which was both inconvenient and dangerous. In 1981, the proportion of the Party members below the age of thirty was 15 per cent; by 1986, this figure was less than 7 per cent (Kołomiejczyk, 1988, p. 297). In the mid-1980s, one fourth of people employed in the Party structures would reach retirement age and could not be replaced. The Party officers were increasingly dominated by the generation shaped in the 1950s (the generation of the Union of Polish Youth), characterized by a conservative and dogmatic approach.

As more and more power was concentrated in the hands of Gen. Wojciech Jaruzelski and the "Directorate" surrounding him, the significance of other bodies, such as the Central Committee and the Political Bureau of the Party, dwindled (Dudek, 2004, p. 47). This was accompanied by the core of the power elite increasingly incorporating persons from the military and security services. Alongside Gen. Jaruzelski and Gen. Kiszczak, an essential role was played by Gen. Dziekan, who was in charge of the Personnel Department at the Central Committee of the Party, Gen. Kołodziejczak, the head of the Chancellery of the Secretariat of the Central Committee, and Gen. Janiszewski, the head of the Office of the Council of Ministers. Military officers were assigned to work both in the Party structures and in the state administration; as many as eleven of them assumed the offices of ministers and deputy ministers, and a further thirteen became regional governors and deputy governors. The same shift could be seen in the civil judiciary, where 108 military prosecutors and judges worked (Paczkowski, 2002a, p. 308). Jaruzelski efficiently removed those he did not trust from the ruling circles, such as the extremely influential Milewski, and in the late 1980s he became a more powerful leader than any of his predecessors.

Changes in the international situation, a deteriorating economy and the above-described erosion of the ruling apparatus in the late 1980s all led to the Party members becoming distinctly demoralized, increasingly pessimistic and seeking new authorities to trust. A survey conducted by the Department of Propaganda of the Central Committee on a representative sample of the Party members in September 1988 revealed markedly poor moods. Nearly 50 per cent of the respondents indicated "discouragement, depression, powerlessness, [and] resignation" to be the dominant sentiment while only 1 per cent believed that the economy would recover (Dudek, 2004, p. 202). Having analyzed the content of letters and complaints received by the Central Committee of the Party, Kisielewski concluded that "the process of the collapse of the communist system in Poland was profoundly and objectively justified in terms of the economy even among communist circles, including the Party authorities" (Kisielewski, 2011, p. 98). The surveys demonstrating that the Primate of Poland Cardinal Józef Glemp was the most trusted person among Party members, above Gen. Jaruzelski, must have come as an exceptional shock to the Party leaders. However, this was far from surprising, as 66 per cent of Party 
members declared themselves church-goers in 1986 (Czerwiński, 2001, p. 83). Even the First Secretary of the Party had no illusions regarding this issue when he told his colleagues from the Party Secretariat: "Comrades, our Party is carrying a horrific hump [...], the hump of religiousness" (Dudek, 2004, p. 82). Interestingly, the pessimistic sentiments raised in the Party did not correspond with refutation of the principles of social security, equality and justice promoted in the official narrative of the Party. During the labor strikes in August 1980, and then in 1988-1989, a large proportion of society did not contest the social principles or equality in Poland's political system, but they rejected the rule of the Party apparatus that had failed to implement those principles.

Under such circumstances, in the late 1980s, the goal of the communist elite was to go through the stage of an inevitable political transformation as painlessly as possible and, more importantly, to dodge the risk of losing power in an uncontrollable manner. As early as the beginning of 1988, an influential circle of advisors to Gen. Jaruzelski, "the Team of Three" made up of Jerzy Urban, Stanisław Ciosek and Gen. Pożoga, presented a general action plan. It boiled down to a move called "co-optation" or "incorporation." It assumed a limited liberalization of the system, and allowed a part of the opposition to operate legally. Its representatives should be given responsibility for the economy and receive one third of seats in the sham Senate that would be established solely for this purpose. The fundamental goal was to divide and disintegrate the opposition rather than to transform the system thoroughly or aim for full political plurality. The report by "the Team of Three" left no doubts in this respect and advocated "including the most tamed elements of moderate opposition within the scope of our influence and institutions" (ibid., p. 127). This scenario was implemented between the fall of 1988 and summer of 1989, although it was significantly reviewed at every stage. The most important correction concerned the decision made at the turn of 1989 to legalize Solidarity. In general, the communist elite was inclined to liberalize the economy to a vast extent as long as this would help them to avoid substantial political concessions. This was particularly visible in fall 1988 in the program of the Mieczysław Rakowski government. Rakowski opted for the philosophy of "the sumptuous table" that should replace "the Round Table." This "Chinese Scenario," where living standard would be improved in exchange for relinquishing broader political freedoms, turned out to be unrealistic, but it triggered the process of "the endowment of the nomenklatura," which was of utmost importance for the ruling elite at the time. The opportunity to change one's status from the manager of state property to a private owner turned out to be an attractive prospect for a considerable segment of the Party nomenklatura (Staniszkis, 2001, pp. 198-199). This was one of catalysts which accelerated the evolution of this circle and its approval of deeper political and social transformations in Poland.

The Round Table negotiations apparently confirmed the claim that the authorities were ready for such changes at that time, but they did not take the ultimate loss of power into account. One feels inclined to agree with Antoni Dudek, who observed that "not wanting to give up the fundamental instruments of power, Jaruzelski's team resolved to provide the moderate part of the opposition with a controlled position in the political system while transferring the true center of political decision-making from the Central Committee of the Party to the office of the President, which would be assumed by Jaruzelski" (Dudek, 2004, p. 272). This scenario was approved by the opposition leaders who 
signed the Round Table agreements, but it was rejected by the circles opting for a radical break with the system.

\section{The opposition}

The quantity, variety and the range of operations of the opposition circles in Poland in the 1980s were unique in the Soviet Bloc. This was due to the social resistance movement historically having been stronger in Poland, where social rebellions cyclically recurred, forming a kind of "rebellion culture" and preventing the consolidation of "normalization processes" such as those that occurred in Hungary after 1956 and in Czechoslovakia after 1968. This resulted in the emergence of Solidarity in 1980-1981, a mass social movement building civic awareness in society and providing solid foundations for the survival of the opposition during martial law. Importantly, the layout of internal divisions inside the opposition originated much earlier, manifesting itself as early as 1976-1981, when the main opposition organizations emerged which would continue their activities into the 1980s (Friszke, 1994, p. 265).

The sentiments of social rebellion quietened in the second half of the 1980s. There were only a few indicators of any future changes. The enthusiasm of 1980-1981 was therefore replaced by apathy and withdrawal from public activity, which was termed "internal migration." Another trend that intensified then involved the pursuit of various adaptation strategies. The memories of the heroic era of the revolution of Solidarity had not been erased, but were manifested through "attitudes rather than actions" (WnukLipiński, 2002, p. 13).

Under these conditions, it was difficult to maintain the activities of the opposition at the same level as before. The opposition was running out of people prepared to get involved in various types of activities, and the infrastructure required to carry them out was difficult to provide. This was evidenced in detail in the reports by special units of the Ministry of the Interior. They show that over a period of just six months, between December 1985 and May 1986, the number of people involved in various forms of opposition activity fell from approximately 14,000 to 10,000 (Dudek, 2004, p. 66). Involvement in the opposition was additionally discouraged by the more pragmatic policy of the authorities. In line with the concepts developed by "the Team of Three" and the Analysis Center at the Ministry of the Interior, the forms of repression against individual persons became more flexible and diverse. The "veterans" and "professionals" were punished severely, but persecutions against those who were only incidentally involved in the activities of the opposition were more moderate. It also became a general rule to charge opponents with criminal rather than political offences, for example, with financial crimes. People involved in anti-systemic activities were encouraged to start businesses in order to later prosecute them as "swindlers" and "speculators" (ibid., p. 65).

The situation began to change in 1987. Given the changing situation in the USSR, the increasingly audible echo of Gorbachev's perestroika and the worsening economic crises, some social groups began to radicalize. This was particularly true for the young generation, from both the intelligentsia and the working class. This process translated into waves of strikes at universities and companies in 1988. Although the strikes were 
directed by opposition veterans who had started their work in 1980, it was the young people who had not been broken by the trauma of martial law who were the driving force of these strikes. They were frequently more radical and determined (ibid., p. 143). Even Lech Wałęsa could get a sense of their attitudes when he faced resistance trying to end the strike at the Gdańsk Shipyard in August 1988. Towards the end of the 1980s, both the authorities and the dominant opposition circles around Lech Wałęsa interpreted this radical turn as something of a threat and an incentive to seek agreement.

At the beginning of the stage of ultimate systemic changes, the opposition was not a unified camp, encompassing numerous differences as to what tactic should be adopted when dealing with the withering authorities on the one hand and the animosities dating back to the previous decade on the other. These divisions were also kindled and sustained by the communist authorities' policy of using operating instruments of the security services to this end. The strongest and most representative opposition group was indisputably the broad circle gathered around the moderate wing of the Solidarity trade union. Its members acknowledged the leadership of Lech Wałęsa and stressed the pursuit of compromise with the authorities. The most important allies surrounding the union leader came from two circles: those who started their opposition activity as part of laic Catholic circles, and those who used to constitute internal opposition inside the Party and were referred to as "revisionists." In the 1970s, these two groups approached each other and formed an alliance, the manifesto of which was a book by Adam Michnik, Kościót, lewica, dialog (published in English as The Church and the Left). Despite all the differences that divided them, Tadeusz Mazowiecki, Bronisław Geremek and Jacek Kuroń, who came from these groups, designed the strategy and tactics of the dominant part of the opposition at that time. In May 1987, the sixty-three people who had been invited by Lech Wałęsa to develop the fundamental principles and goals of Solidarity issued a statement where they defined them as follows: "Poles have the right to independence, [...] to live in democracy, freedom, truth, respect for law and to develop the economic order on their own. [...] If such ideas as freedom of conscience and belief, freedom of association in trade unions, social and cultural organizations, and freedom of speech are not implemented, one can hardly speak about the state, economy and culture operating as normal." The statement opted for collaboration with all people who pursued "true social agreement" and renounced all forms of violence in favor of "the philosophy of working for the country" (Polski rok..., 2009, pp. 18-20).

Based on these ideas, the process of forming a uniform center that could become a partner in the process of developing an agreement with the authorities began. Its foundations were laid by the Solidarity National Executive Committee, established on October 31, 1987, as the first overt, albeit still illegal, leadership of the union. The political body that represented moderate opposition circles in Solidarity was eventually constituted on December 18, 1988 as the Citizens' Committee. It was formed on the eve of the Round Table negotiation process in view of taking part in the talks. It was formed of members of the public, academia and artists who were widely respected and were officially invited to the Committee by Lech Wałęsa. Therefore, the Citizens' Committee was not strictly a labor union institution but a broad civic initiative. The action program implemented by the Committee was a continuation of the guidelines set out in the May 1987 document quoted above, although the former more strongly stated the intention to 
reach a broad compromise with the authorities. The opposition did not envisage assuming political power any time soon, nor gaining a multi-party system or free elections; instead, the need to forge democratically elected, authentic local government was focused upon. The then-authorities were expected to continue their domination of central state bodies, security and foreign affairs. The opposition circles indicated the disastrous condition of the economy and committed themselves to cooperating in overcoming the crisis (Luczak, 2010, p. 578). The action plan developed by the most important opposition circle was therefore quite conservative in nature and did not diverge significantly from the goals that the authorities were pursuing at the time as part of the reviewed "cooptation scenario."

The Citizens' Committee rejected radical tactics, facing criticism from those opposition circles that had contested the ideas of the group surrounding Lech Wałęsa earlier. These opposition groups were quite diverse and embraced organizations dating back longer than Solidarity, which had clearly spelled out their pursuit of independence from the beginning. The Confederation of Independent Poland (Polish: Konfederacja Polski Niepodległej), founded by Leszek Moczulski, was the most important organization here. There were also critics of the idea of compromise inside the trade union, including a group of its leaders in the early 1980s, such as Gwiazda, Walentynowicz, Jurczyk and Wyszkowski, who were in conflict with Wałęsa at the time. In March 1987, they formed the Working Group of the National Commission of the Solidarity Trade Union and remained relentless during the 1988-1989 transformation, rejecting any agreement with the authorities whatsoever (Hall, 2011, p. 20). Also, the Fighting Solidarity (Polish: Solidarność Walczaca) established by Kornel Morawiecki as early as 1982 chose the same path. These circles were not represented in the Citizens' Committee. This was also a conscious decision made by Wałęsa's closest advisors, who wanted to form a team that would present a uniform standpoint in front of the Polish authorities and be immune to any attempts at dividing them (Dudek, 2004, pp. 233-237). The scenario of "Wałęsa's team" was selected at the expense of the representativeness. This sparked controversies as early as in the end of 1988, which were a harbinger of much deeper divisions to come. The opposition was embarking on the most crucial stage of the transformation with no uniform action plan. Its strength was ensured by growing social dissatisfaction and assistance provided by the Catholic Church, which was more powerful than ever before or since.

\section{The Church}

The role the Catholic Church played in the transformation process in Poland in 1988 and 1989 was the culmination of the tactic adopted by Church representatives, first and foremost by Cardinal Stefan Wyszyński, in their dealings with the policies of communist authorities that were hostile to Catholicism. This tactic uniquely combined steadfastness and far-reaching realism and pragmatism, allowing the Catholic Church to retain the public trust it had enjoyed as, for some time, the only institution supporting social resistance. At the same time, the Church maintained a minimum level of modus vivendi with the representatives of the system, obtaining relative freedom of operation and pro- 
tecting the Church against repressions that might otherwise have destroyed its autonomy. Thanks to this combination of steadfastness and realism, the Church took the position of an arbiter, mediator and guarantor in the process of dispute and reconciliation between the authorities and the opposition in the late 1980s.

Towards the end of the communist era, the Church in Poland faced a policy by which the state authorities continued to approach it as an enemy hampering the implementation of an ideological project and tried to curb its scope of social influence. In the late 1980s, however, the capacity of the authorities to affect the Church was considerably restricted and Poland's communist leaders were increasingly aware of its permanent presence and operation among Polish society. Gen. Jaruzelski talked to Erich Honecker about it, using his favorite hump metaphor: "Half in jest one could say that this is a hump you cannot have surgically removed, something you have to live with. In my opinion, from a medical point of view, this is infeasible" (Polska 1986..., vol. III, 2002, p. 52).

One of the factors decisive for the social and political power of the Church in Poland in the 1980s was the pontificate of John Paul II. The Polish Pope was of course extremely interested in the situation in his country, and was more familiar with this situation than his predecessors. It is another matter whether the words and actions of the Pope and certain members of Polish hierarchy were congruent (Weigel, 2001, p. 584). Certain differences could be seen at least at the level of words: "while Primate Glemp appears to have run out of patience with it [Solidarity], the Pope continues to demonstrate a certain sentiment towards it and revives this theme. At present, it is difficult to determine whether this is a legitimate difference or a theatrical role play," wrote analysts from the Ministry of the Interior in 1987 (Dudek, 2004, p. 81). Yet attempts by communist authorities to establish diplomatic relations with the Vatican, launched at the beginning of 1986, stood no chance of succeeding. The policy of seeking contact with the Vatican diplomacy over the heads of Polish bishops might have worked during the pontificate of Paul VI, but it was clearly unrealistic while his successor was in office. To begin any talks in this field, it was a prerequisite for the Polish Church that the law on the relationship between State and the Church be adopted to restore the status of legal person to the latter; this was also the position of the Vatican. The attempts to walk the paths Poland had trod in the 1970s were no longer effective. The intensifying internal crisis combined with the weakening international position of the regime forced it to seek help among the Church hierarchy.

Even though the authorities were aware of the situation, they did not cease to see the Church as an ideological opponent, nor gave up operational activities against representatives of the Church. The authorities sought to profile the role of the Church and use what Gen. Jaruzelski called "the stick and carrot" mechanism to bring the Church down to the position of a stabilizer of the politico-social situation in Poland (Poufny ..., 1992). That is why the authorities tried to win the loyalty of the Church hierarchy by offering to regulate the legal position of the Church on the one hand and intensifying repressions against the rebellious members of lower clergy on the other (Metody..., 2004). Interestingly, the position of communist authorities grew weaker, making this policy utterly unsuccessful, and using "the stick" was both problematic and ineffective. Therefore, the authorities increasingly relied on the skillful distribution of "the carrot." The role of the Church was growing, which was noted by state authorities, leading them to totally reverse their initial policy aimed at the marginalization of the Church. It can be said with some caution that 
when the authorities resolved to incorporate the opposition into the reform process, the institutionalization of the Church's role in this process began, with this role going far beyond the religious dimension.

This could already be seen in the first half of 1988, during numerous contacts between the Episcopacy and the authorities, conducted most frequently by Stanisław Ciosek and Rev. Alojzy Orszulik, the head of the Episcopal Press Office. The Polish authorities expected that the Church would moderate the attitudes of the opposition as overtly expressed in the question: "Will the Church take responsibility for Solidarity?" (Raina, 1999, p. 199). During the increasingly frequent talks held by the representatives of the Church and the Party, they addressed the matters of plurality of labor unions, the shape of the law on associations, elections to national councils, some aspects of foreign policy and the socio-economic situation.

The Church was more and more acknowledged to be irreplaceable in the transformation process from week to week. Shortly before the first talks between Kiszczak and Wałęsa that had been intermediated by the Church representatives, the above-mentioned institutionalization of the role of the Church in Poland produced a proposal for a pact between the Church and State concerning the upcoming Round Table negotiations (ibid., p. 210). Importantly, the Church representatives tended to be cautious and skeptical about the institutionalization the authorities were tempting them with. Mutual talks addressed a broad range of issues, but the Church declined any proposals to institutionally become a party to the transformation processes. This marked aversion of Church representatives to engage in an overt and public dialog with the authorities, while being deeply involved in covert and informal contacts, might be explained in terms of the hierarchical institutional character of the Church, which is not transparent by nature. This might have actually facilitated relations with representatives of the communist state structures, which were also far from transparent. Rev. Orszulik suggested "caution when reporting good relations and dialog with the Church to the Party members, because such messages spread in society and can possibly spark distrust" in his conversation with Ciosek, who replied with full understanding that "the Church has to reckon with its foundations the same way we have to." This meaningful quote carries the spirit of a specific agreement between the Church and the Party based on opaque and informal relations. It was not a coincidence that, in choosing the representative of the authorities to talk with his counterparts in the opposition and the Church in 1988, Gen. Jaruzelski appointed Gen. Czesław Kiszczak instead of Mieczysław Rakowski. Nominating Kiszczak, Jaruzelski emphasized the trust enjoyed by the Minister of the Interior among the upper echelons of the Church (Codogni, 2009, p. 156). It is a paradox that the Church representatives, who had been formed by a specific institutional culture, found a common language with the head of the security services easier than with the ex-editor of the Polityka weekly, who, albeit liberal, harbored a multitude of ideological and anticlerical biases.

The Church engaged in a double strategy, trying to make the most of the compromise offered by the authorities on the one hand while supporting the liberal Church-friendly factions of the opposition. This occasionally caused misunderstanding between the bishops on one hand and priests who were active in the opposition on the other. The latter were seen by their superiors as irresponsible, as exemplified by the conflict between Cardinal Józef Glemp and Rev. Jerzy Popiełuszko (Czaczkowska, 2004, pp. 214-220). 
The Church had been expected to play key role in the "co-optation manoeuver" planned by the authorities since the beginning of 1988. The Church was believed to weaken the resistance and moderate the fears of opposition representatives, who were highly dependent on support from the Church. That was why work on developing legal regulations of the Church's status in Poland, abandoned in 1983, was resumed in 1988, and the mutual relations between the government and Episcopacy within the framework of the Joint Commission intensified (Komisja ..., 2011).

It is therefore not surprising that the officially-authorized representatives of the Church played a key role in preparing the Round Table talks that began in the fall of 1988. During these preparations, both parties believed that the presence of the Church would secure their fundamental interests. Solidarity did not trust the authorities, and saw the Church delegates as witnesses "keeping an eye" on the authorities. The authorities perceived the Church as a moderating influence on the radical attitudes of the opposition, which could persuade them to accept the "co-optation scenario." The Church was represented at this stage by Rev. Alojzy Orszulik and Bishop Tadeusz Gocłowski, and less frequently by Archbishop Bronisław Dąbrowski, who appeared to be more committed than during the Round Table talks proper (Orszulik, 2006, passim). By no means can their engagement be reduced to acting as witnesses and intermediaries between the authorities and the opposition. A certain informal modus operandi was forged then, to be later applied during the Round Table talks. Zbigniew Bujak wrote that: "In Magdalenka nothing is written down, everything is agreed verbally. So when one party comes to a conclusion that the other are not keeping their part of the agreement, they appeal to observers from the Church, and they ultimately decide who is right" (Gebert, 1990, p. 58). During the talks, Rev. Orszulik repeatedly addressed individual topics and social, economic and political matters, such as local government reform, plurality of labor unions and foreign debt (Gocłowski, 1998, p. 125). The Church could hardly be perceived as politically neutral, something state authorities strongly desired, and its representatives increasingly emphasized their role as patrons of the opposition camp.

The informal and behind-the-scenes actions of the Church representatives turned out to be exceptionally important during the Round Table talks, especially during the informal meetings in Magdalenka that were decisive for the success of the entire undertaking. All the accounts of the talks, presented by both sides, emphasize the determination of Bishop Gocłowski and Revs. Orszulik and Dembowski, who worked tirelessly to keep the talks on track despite frequent interruptions and breakdowns in communication. It is difficult to clearly determine how decisive their efforts were for the final compromise, but they evidence the belief held within the Church that it was highly desirable to maintain contacts between the authorities and the opposition. From the Church's point of view, these contacts were directly related to the process of the legal stabilization of the Church's position in Poland, concluded on May 17, 1989 by the adoption of a package of Church Acts by the Polish parliament. The pursuit of this goal strengthened the determination of the Church hierarchy to support the governmentopposition agreement, while the authorities repaid by this token the specific debt owed to the Church after its support in recent months (Borecki, 2008, p. 37). Both the active attitude of the Church representatives during the Round Table talks and the authority 
they enjoyed on both sides made the Church an unofficial signatory of the Round Table contract (Dudek, 2003, p. 436).

The Church was equally active before the elections on June 4, 1989. The electoral campaign of the candidates from the Citizens' Committee, or "Wałęsa's team," was practically based on and dependent solely on Church structures. With a few significant exceptions, bishops and lower clergy gave their unconditional support and engaged in their electoral campaign. On the eve of the campaign, the opposition faced an extremely difficult task, as they lacked the organizational capacity necessary to run the campaign, including funding, facilities and resources necessary to print electoral materials. It was in these matters that the Church's help proved irreplaceable. The engagement of the Church could be seen at every stage of the electoral campaign. Without the Church, it would have been markedly more difficult to organize local Citizens' Committees. At least half of them were accommodated on the premises of parishes and Catholic Intelligentsia Clubs, taking advantage of the entire infrastructure available there. Opposition candidates would frequently be presented during services in churches, and electoral messages were conveyed by way of parochial announcements (Koseła, 2003, pp. 177-221). Another stage involved appointing and supporting concrete candidates. As a rule, the clergy supported the candidates of the Citizens' Committee. The clergy was also highly supportive of the campaigns collecting signatures supporting Solidarity candidates.

The most important aspect, however, involved the support granted by the Church to the Citizens' Committee electioneering. It was standard practice for electoral meetings with voters to be organized on church premises and using church printing facilities; curial printing houses and the printing house of the Lublin Catholic University worked for the campaign. In the critical stage of the electoral fight, in late May and early June 1989, Church representatives would sometimes calm raging emotions and act as moderators at meetings with the candidates, educated churchgoers on the quite complicated electoral technicalities at the time, organized transportation, catering and accommodation for the candidates on the road, and prayed in public for the opposition to win (Codogni, 2012, pp. 192-205).

The Church representatives were among the leading architects of the 1988-1989 events, but it is difficult to clearly determine to what extent their involvement followed from their pursuit of social good and to what degree it was dictated by practical analysis of their own needs and interests. It is quite likely that the Church did not distinguish these two motivations, because its representatives had traditionally identified the interest of the Church with those of the nation and state. The authority of the Church continued to expand and reached its peak in the late 1980s, making the Church the core of the most important elements of the political agenda of both the opposition and the authorities. The latter concluded that support from the Church hierarchy was indispensable to carry out their plans and prevent the outbreak of social dissatisfaction and an uncontrollable loss of power, by means of supervised liberalization and sharing power with the moderate opposition. For this to succeed, support from the Church was necessary and advantageous, albeit inconvenient, for the authorities. Under these circumstances, the Church succeeded and gained the rights it had been deprived of in the early years of the Polish People's Republic. 
In studies of different transformation models implemented in the Soviet Bloc in the late 1980s and early 1990s, the events in Poland and Hungary are frequently compared. Similar historical contexts shared by these countries and societies should have produced a similar course of events before and during "the Fall of the Peoples" (Wojnicki, 2006, p. 119). An analysis of the concepts and actions of the three main actors of the transformation leads to the conclusion that the case of Poland was so exceptional that it should be classified as unique. One key feature of this uniqueness was the tripartite participation of the authorities, the opposition and the Church. The extent of the delegitimization of the communist elite appears greater in the Polish society than anywhere else in the Soviet Bloc. This is the outcome of historical determinants on the one hand, and the acute crisis dating back to the mid-seventies on the other. No other "people's democracy" developed such a varied mass democratic opposition; nowhere else did this opposition exert such a profound influence on social sentiments using extensive "second circulation" publishing, among other things. The key distinctive feature of the Polish transformation model is clearly the Catholic Church. The Church can be said to have played two roles. Firstly, it was a powerful institution that had retained autonomy from the political system of the Polish People's Republic, preventing a more complete implementation of the totalitarian model of state and society. Thanks to a certain "freedom zone" created by the Church, some autonomy in terms of spiritual and intellectual life in Poland could be retained. It is difficult not to interpret this as the fundamental factor in disseminating social resistance in Poland. Secondly, the Church played an essential role during the groundbreaking period in 1988 and 1989. This role was grounded on the social capital that the Church had accumulated earlier, and it allowed a certain synergy to be produced, leading to the implementation of a transformation model devoid of confrontation even in the face of all the differences between the parties.

\section{Bibliography}

Borecki P. (2008), Geneza modelu stosunków państwo-Kościót w Konstytucji RP, Wyd. Sejmowe, Warszawa.

Codogni P. (2009), Okragły stót, czyli polski rubikon, Prószyński i S-ka, Warszawa.

Codogni P. (2012), Wybory czerwcowe 1989 roku. U progu przemiany ustrojowej, IPN, Warszawa.

Czaczkowska E., Wiścicki T. (2004), Ksiądz Jerzy Popietuszko, Świat Książki, Warszawa.

Czerwiński M. (2001), Religia w ideologii PZPR lat 80, in: Między integracja a komunizmem: spoteczeństwa i kościoły Europy środkowej, eds. K. Kowalczyk et al., Mała Poligrafia Redemptorystów, Tuchów.

Dąbek K. (2006), PZPR - retrospektywny portret wlasny, Trio, Warszawa.

Dudek A. (2004), Reglamentowana rewolucja. Rozkład dyktatury komunistycznej w Polsce 1988-1990, Arcana, Kraków.

Dudek A., Gmyz R. (2003), Komuniści i Kościót w Polsce (1945-1989), Znak, Kraków.

Friszke A. (1994), Opozycja polityczna w PRL 1945-1980, Aneks, Londyn.

Gawin D. (2015), Wielki zwrot. Ewolucja lewicy i odrodzenie idei społeczeństwa obywatelskiego 19561976, Znak, Kraków.

Gebert K. (1990), Mebel, Aneks, Londyn.

Gocłowski T., Hlebowicz A. (1998), Świadek, Prószyński i S-ka, Warszawa. 
Hall A. (2011), Osobista historia III Rzeczpospolitej, Rosner\&Wspólnicy, Warszawa.

Kisielewski T. (2011), Partii portret własny. Polityka i świadomość w PZPR-studium upadku, Neriton, Warszawa.

Kołomiejczyk N. (1988), Polska Zjednoczona Partia Robotnicza 1948-1986, Książka i Wiedza, Warszawa.

Komisja Wspólna Rządu Rzeczpospolitej Polskiej i Konferencji Episkopatu Polski w archiwaliach lat 1989-2010 (2011), selected and edited by P. Borecki, C. Janik, Wyd. Sejmowe, Warszawa.

Koseła K. (2003), Polak i katolik splatana tożsamość, IFiS PAN, Warszawa.

Kowal P. (2015), Koniec systemu władzy. Polityka ekipy gen. W. Jaruzelskiego w l. 1986-1989, Narodowe Centrum Kultury, Warszawa.

Łuczak A. (2010), Dekada polskich przemian. Studium władzy i opozycji, ASPRA-JR, Warszawa.

Metody pracy operacyjnej aparatu bezpieczeństwa wobec kościołów i zwiazków wyznaniowych (2004), ed. A. Dziurok, IPN, Warszawa.

Orszulik A. (2006), Czas przełomu. Notatki z rozmów z władzami PRL w latach 1981-1989, Apostolicum, Warszawa-Ząbki.

Paczkowski A. (2002), Boisko wielkich mocarstw: Polska 1980-1989. Widok od wewnątrz, "Polski Przegląd Dyplomatyczny", nr 3.

Paczkowski A. (2002a), Droga do „mniejszego zła”. Strategia i taktyka obozu władzy, Wydawnictwo Literackie, Kraków.

Polska 1986-1989. Koniec systemu, t. III: Dokumenty (2002), eds. A. Dudek, A. Friszke, Trio, Warszawa.

Poufny dokument KC PZPR z 1986 r. o polityce wobec Kościoła (1992), “Więź”, no. 11.

Polski rok 1989: sukcesy, zaniechania, porażki, Część 2 (2009), eds. M. Jabłonowski, S. Stępka, S. Sulowski, Ad Astra, Warszawa.

Raina P., Droga do Okragłego Stotu. Zakulisowe rozmowy przygotowawcze, Wyd. von Borowiecky, Warszawa.

Staniszkis J. (2001), Postkomunizm. Próba opisu, Słowo/Obraz/Terytoria, Gdańsk.

Sztompka P. (2007), Socjologia zmian społecznych, Znak, Kraków.

Weigel G. (2001), Świadek nadziei. Biografia papieża Jana Pawła II, Świat Książki, Warszawa.

Wnuk-Lipiński E. (2002), Nastroje społeczne w latach 1986-1989, in: Polska 1986-1989. Koniec systemu, t. I: Referaty, eds. A. Dudek, A. Friszke, Trio, Warszawa.

Wojnicki J. (2006), Modele zmiany politycznej w Europie Środkowo-Wschodniej w l. 1989-1990, in: Pokojowa rewolucja jako instrument zmiany politycznej $w$ krajach postkomunistycznych na przełomie XX i XXI wieku, eds. J. Macała, R. Potocki, A. Janiak, Druk-Ar, Zielona Góra.

Zmierzch dyktatury. Polska lat 1986-1989 w świetle dokumentów (2013), t. I, ed. A. Dudek, IPN, Warszawa.

\section{Przemiany lat 1988-1989 w Polsce. Władza, opozycja, Kościół}

\section{Streszczenie}

Wydarzenia, które miały miejsce w Polsce w latach 1988-1989, stworzyły model transformacji, którego różne elementy były zazwyczaj powielane w innych krajach bloku sowieckiego. Niektóre elementy polskiego modelu transformacji były jednak specyficzne i niepowtarzalne, wyrastały z określonego kontekstu historycznego. Autor artykułu proponuje, aby triada utworzona przez ,władzę, opozycję i Kościół" została uznana za wyjątkowo polski aspekt transformacji polityczno-społecznej, która miała miejsce po sierpniu 1980 roku. Celem artykułu jest przedstawienie tej trans- 
formacji w odniesieniu do każdego z powyższych trzech aktorów. Analiza ich koncepcji i działań prowadzi do wniosku, że Polska powinna być uznana za wyjątkowy model transformacji w Europie Środkowo-Wschodniej. W polskim modelu transformacji znalazł się kluczowy i niepowtarzalny element, jakim jest Kościół katolicki - instytucja, która odegrała znaczącą rolę w uczynieniu transformacji 1988-1989 niekonfrontacyjną.

Slowa kluczowe: zmiana systemowa 1989, model transformacji 1989, Polska 1989, Kościół katolicki 1989 